\title{
Inflammatory Myofibroblastic Tumor Driven by Novel NUMA1-ALK Fusion Responds to ALK Inhibition
}

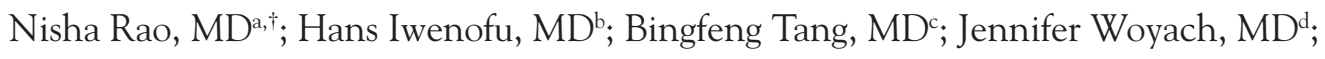
and David A. Liebner, MDe,f

\begin{abstract}
Inflammatory myofibroblastic tumors (IMTs) are soft tissue neoplasms with rare metastatic potential. Approximately half of IMTs are positive for an $A L K$ rearrangement, and ALK inhibitors have been used successfully in the treatment of IMTs with a variety of $A L K$ fusions. This report describes a 21-year-old woman with an aggressive, metastatic IMT with a novel NUMA1-ALK fusion that showed a dramatic response to the ALK inhibitors crizotinib and alectinib. To our knowledge, this report provides the first published description of an IMT with a NUMA1-ALK fusion. The patient's aggressive IMT responded favorably to crizotinib and alectinib, suggesting that ALK inhibitors may be effective in IMT with NUMA1-ALK fusions. We review published reports of $A L K$-driven IMTs that have received ALK inhibitor therapy and suggest characteristics that may be associated with favorable response to treatment. We also discuss the strengths and limitations of immunohistochemistry, fluorescence in situ hybridization, and next-generation sequencing in the diagnosis and management of IMTs.
\end{abstract}

J Natl Compr Canc Netw 2018;16(2):115-121 doi: 10.6004/jnccn.2017.7031

Inflammatory myofibroblastic tumors (IMTs) are rare soft tissue neoplasms that usually arise in the lung, abdomen, or pelvis and affect primarily children and young adults. ${ }^{1}$ IMTs are usually localized and metastatic disease is rare, accounting for $<5 \%$ of all cases. ${ }^{2}$ IMTs most often present with signs and symptoms restricted to the areas affected; however, $15 \%$ to $30 \%$ of people present with fever, weight loss, malaise, microcytic anemia, elevated erythrocyte sedimentation rate, thrombocytosis, or polyclonal hypergammaglobulinemia. ${ }^{3}$ Although the histology of IMT is variable, tumors are generally composed of spindle cells in an inflamed stroma of plasma cells, lymphocytes, and eosinophils. ${ }^{2}$ Surgery is the pri-

From the a Ohio State University College of Medicine; ' ${ }^{\circ}$ ivision of Soft Tissue and Bone Pathology, Department of Pathology; 'Department of Radiology; dDivision of Hematology, Department of Internal Medicine; eDivision of Medical Oncology, Department of Internal Medicine; and fDivision of Computational Biology and Bioinformatics, Department of Biomedical Informatics, College of Medicine, Ohio State University، Columbus, Ohio.

${ }^{\dagger}$ Current affiliation: New York Presbyterian Hospital and Columbia University, New York, New York. mary management modality; however, lesions may recur after surgical resection. ${ }^{2}$

Recent evidence suggests that the anaplastic lymphoma kinase $(A L K)$ gene plays a role in the pathogenesis of some IMTs. ALK encodes a receptor tyrosine kinase normally expressed only in neural tissue, ${ }^{4}$ and rearrangements of $A L K$ can result in inappropriate activation of the ALK receptor tyrosine kinase..$^{5}$ Approximately half of IMTs are associated with an ALK gene rearrangement. ${ }^{6}$ Fusions of ALK with TPM3, TPM4, ATIC, CLTC, CARS, RANBP2, EML4, and SEC31L1 have been described previously.
Submitted March 21, 2017; accepted for publication September 5, 2017.

The authors have disclosed that they have no financial interests, arrangements, affiliations, or commercial interests with the manufacturers of any products discussed in this article or their competitors.

Correspondence: David A. Liebner, MD, Division of Medical Oncology, Department of Internal Medicine, Ohio State University, 460 West 10th Avenue, Columbus, OH 43210. E-mail: David.Liebner@osumc.edu 
ALK inhibitors have emerged as a successful therapy for ALK-associated IMT in both adult and pediatric patients. ${ }^{8-14}$ To our knowledge, however, the response of IMT associated with a NUMA1-ALK fusion has never been documented. This report describes a 21-year-old patient with widely metastatic IMT with a NUMA1-ALK fusion who demonstrated a marked response to ALK inhibitor therapy. We then review published reports of ALK-driven IMT treated with ALK inhibitors and suggest predictors of favorable response to treatment.

\section{Case Description}

\section{Clinical Course}

A 21-year-old woman initially presented with left shoulder pain and left arm swelling. She reported that she had experienced a 10- to 15-pound weight loss during the preceding year, a few months of fatigue and dry cough, and a few weeks of shortness of breath and dysphagia. She had also experienced intermittent night sweats and left-sided pleuritic chest pain, all of which had worsened acutely over the past month.

She was diagnosed with an acute deep vein thrombosis of her left internal jugular vein. On further evaluation, she was found to have a large mediastinal mass encasing multiple mediastinal structures and lesions involving the lungs, liver, spleen, kidney, bone, peritoneum, and iliacus muscle. A staging PET/CT scan showed multiple hypermetabolic lesions above and below the diaphragm, involving the mediastinum and left hemithorax, bilateral lungs, pleura, liver, left kidney, axial skeleton, and musculature (Figure 1A). Differential diagnosis at the time included lymphoma and metastatic germ cell tumor.

Biopsies of a lung mass and a left supraclavicular lymph node were performed. Histologic sections from both samples revealed a spindle cell proliferation that was variably cellular, with broad areas of fibrosis and obscuring lymphoplasmacytic infiltrates, without evidence of high-grade anaplastic features, coagulation tumor necrosis, or atypical mitotic figures (Figure 2). On immunohistochemistry (IHC), lesional cells showed unequivocal, strong, and diffuse reactivity for ALK (in a cytoplasmic and perinuclear pattern) and weak focal reactivity for smooth muscle actin and desmin. Other markers, including CD45, CD3, CD20, CD163, CD15, CD30, EBER, PAX5, pan cytokeratin-AE1/AE3, S100, and pan cytokeratin-MNF116, were negative. Plasma cells stained diffusely for both Kappa and Lambda with no evidence of light chain restriction. Fluorescence in situ hybridization (FISH) testing was reported as negative for ALK translocation; however, next-generation sequencing (NGS) by Foundation Medicine (Cambridge, MA) revealed a novel NUMA1-ALK fusion. The ALK translocation was detected on both DNA and RNA sequenc-
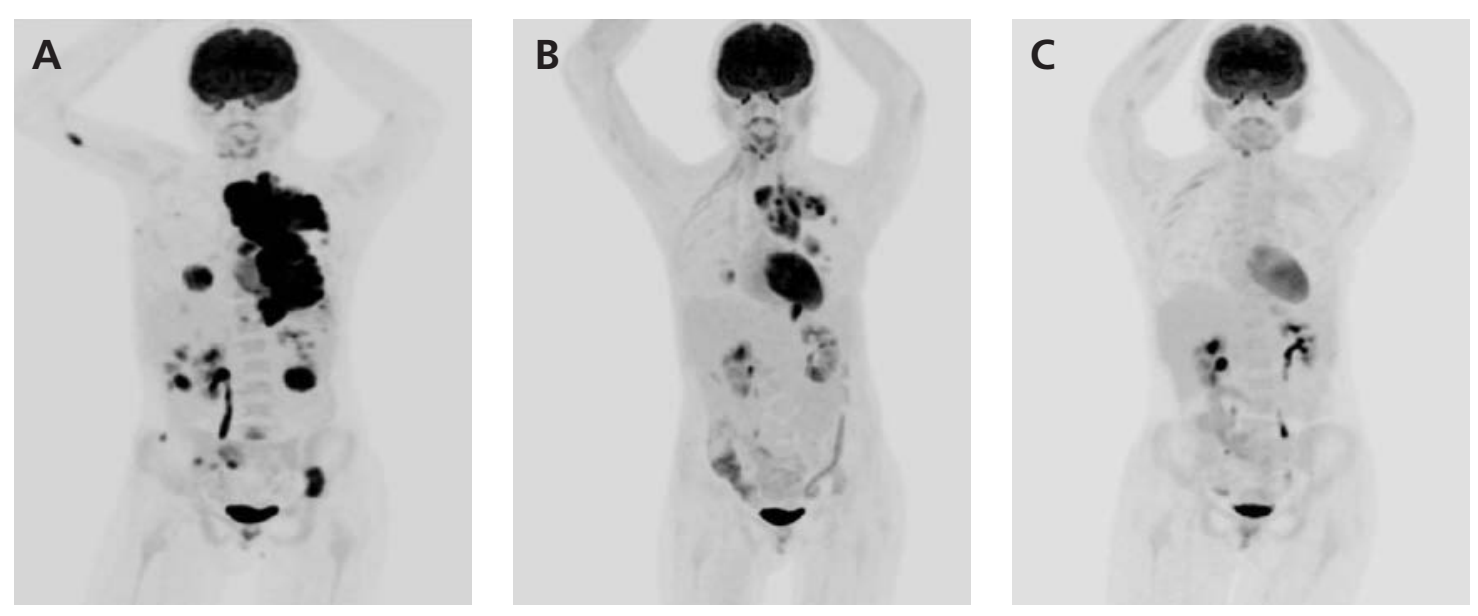

Figure 1. PET/CT demonstrating burden of disease. (A) At initial presentation, PET/CT demonstrated multiple hypermetabolic lesions above and below the diaphragm involving the mediastinum, bilateral lungs, left pleura, liver, left kidney, abdomen, axial skeleton, and musculature (maximum standardized uptake value $\left.\left[\mathrm{SUV}_{\max }\right], 48.7\right)$. (B) One month after crizotinib therapy initiation, PET/CT demonstrated reduced size and FDG avidity of several hypermetabolic masses/lesions involving the lung/pleura, liver, and bone, as well as the left perinephric region (SUV $\mathrm{max}_{1}, 14.1$ ). (C) After 6 months of crizotinib therapy, patient was switched from crizotinib to alectinib for concern for possible contribution of crizotinib to her pneumonitis. A PET/CT performed one month after beginning alectinib demonstrated further reduction in FDG avidity of neck, chest, and bone lesions (SUV ${ }_{\text {max' }}{ }^{1.9)}$ ). 


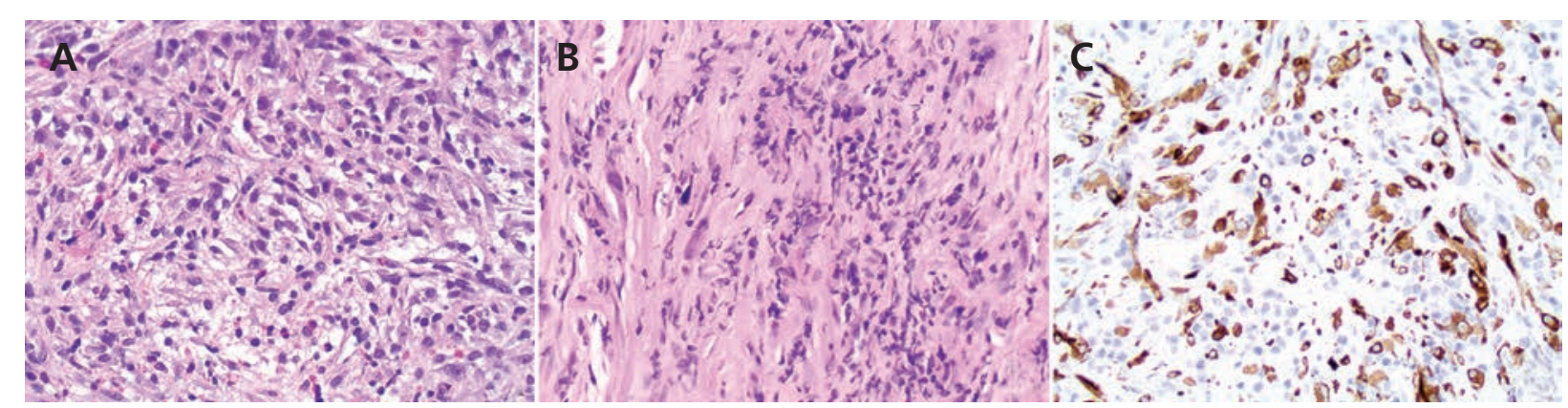

Figure 2. Histology sections from biopsy samples. (A) Sections showing a banal spindle cell proliferation in swirling growth pattern punctuated with sprinkling of chronic inflammatory cells and eosinophils (hematoxylin-eosin, original magnification x200). (B) High power view showing areas with obscuring lymphoplasmacytic infiltrates (hematoxylin-eosin, original magnification x400). (C) Lesional cells demonstrating diffuse and strong ALK reactivity (ALK, original magnification $\mathrm{x} 400$ ).

ing analyses. The following fusion was discovered: 5'-NUMA1(ex1-19 NM_006185)-ALK(ex20-29 NM_004304) (Figure 3). The depth of sequencing was adequate, with a 755 median exon depth for the whole specimen. Taken together, these results were consistent with an ALK-driven IMT.

When the patient was scheduled to begin therapy, NGS results were still pending. Given the strong reactivity for ALK by IHC, she was started on crizotinib, $250 \mathrm{mg}$ twice daily. At 2-week followup, the patient's symptoms had markedly improved: her dry cough had resolved, she felt less pressure in her chest, and she was able to eat and swallow pills. Apart from lower-abdominal cramping, which was controlled with hyoscyamine, she tolerated crizotinib therapy well.

Four weeks after beginning crizotinib, a restaging PET scan showed pronounced improvement, with reductions in size and FDG avidity of multiple hypermetabolic masses involving the lung, pleura, liver, left perinephric region, and osseous lesions

\section{Chromosome 2}

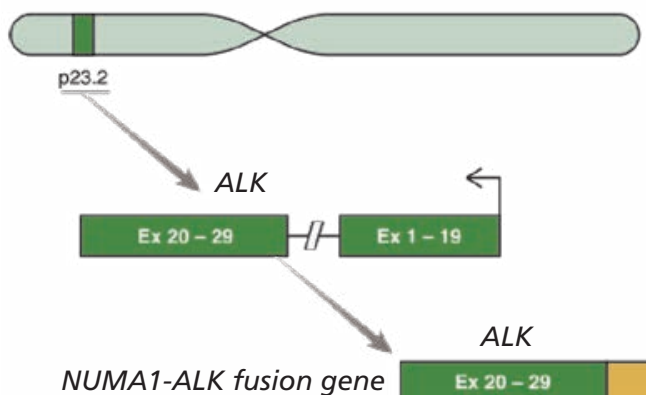

(Figure 1B). Improvement was specifically noted in a left lower lobe mass (maximum standard uptake value $\left[\mathrm{SUV}_{\max }\right]$ decreased from 48.7 to 14.1 ), right lower lobe lesion $\left(\mathrm{SUV}_{\max }, 17.7\right.$ to 6.6), left kidney mass $\left(\mathrm{SUV}_{\max }, 16.7\right.$ to 8.0$)$, and right sacral lesion $\left(\mathrm{SUV}_{\max }, 12.4\right.$ to 4.2$)$.

Six weeks after beginning crizotinib, nivolumab at $3 \mathrm{mg} / \mathrm{kg}$ intravenously every 2 weeks was added to her regimen given evidence of high-positive PD-1 expression in tumor-infiltrating lymphocytes (>25\%, clone NAT105 by Cell Marque; Rocklin, CA). She received 12 weeks of combination therapy with crizotinib and nivolumab with continued radiographic response to therapy. However, she developed grade 2 pneumonitis and grade 3 transaminitis, suspected to be related to nivolumab and possibly to crizotinib. Both agents were held and she was treated with prednisone, $1 \mathrm{mg} / \mathrm{kg} / \mathrm{d}$, after which she experienced rapid improvement in her pneumonitis and normalization of her transaminases. Prednisone was tapered slowly over 6 weeks and crizotinib was
Chromosome 11

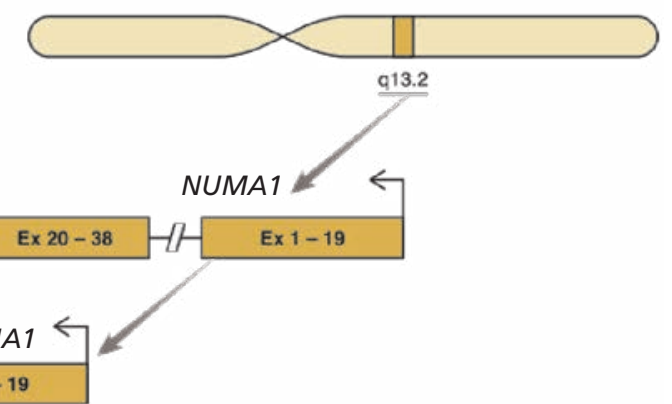

Figure 3. Illustration of the NUMA1-ALK fusion. 
Rao et al

\begin{tabular}{|c|c|c|c|c|c|c|c|c|c|}
\hline Study & ALK-Fusion & $\begin{array}{l}\text { Age, } \\
y\end{array}$ & Sex & $\begin{array}{l}\text { Organ } \\
\text { Involvement }\end{array}$ & $\begin{array}{l}\text { Pathology } \\
\text { Features, } \\
\text { General }\end{array}$ & $\begin{array}{l}\text { ALK } \\
\text { Localization }\end{array}$ & $\begin{array}{l}\text { Prior Systemic } \\
\text { Therapies }\end{array}$ & $\begin{array}{l}\text { ALK } \\
\text { Inhibitor }\end{array}$ & $\begin{array}{l}\text { Response/ } \\
\text { Management }\end{array}$ \\
\hline $\begin{array}{l}\text { Butrynski et } \\
\mathrm{al}_{,}, 2010\end{array}$ & RANBP2-ALK & 44 & $\mathrm{M}$ & $\begin{array}{l}\text { Ascites, RUQ mass, } \\
\text { omental caking }\end{array}$ & $\begin{array}{l}\text { Mostly epithelioid } \\
\text { cells with large } \\
\text { vesicular nuclei, } \\
\text { prominent nucleoli, } \\
\text { amphophilic } \\
\text { cytoplasm, embedded } \\
\text { in a myxoid stroma; } \\
\text { neutrophilic infiltrate }\end{array}$ & Nuclear membrane & $\begin{array}{l}\text { Tumor debulking; } \\
\text { hyperthermic } \\
\text { peritoneal perfusion } \\
\text { of cisplatin, } \\
\text { doxorubicin, } \\
\text { mitomycin C; } \\
\text { doxorubicin and } \\
\text { ifosfamide followed } \\
\text { by imatinib } \\
\text { maintenance therapy }\end{array}$ & Crizotinib & $\begin{array}{l}\text { Partial response at } 2 \text { months; } \\
\text { progression noted } 7 \text { months } \\
\text { after starting therapy; } \\
\text { patient underwent surgical } \\
\text { debulking and crizotinib } \\
\text { dose increased; complete } \\
\text { remission at } 30 \text { months }\end{array}$ \\
\hline $\begin{array}{l}\text { Gaudichon et } \\
\mathrm{al}^{,}{ }^{2} 2016\end{array}$ & EML4-ALK & 16 & $\mathrm{~F}$ & Left shoulder mass & $\begin{array}{l}\text { Elongated } \\
\text { spindle cells with } \\
\text { amphophilic } \\
\text { cytoplasm, centered } \\
\text { on enlarged and } \\
\text { moderately atypical } \\
\text { nuclei harboring } \\
\text { fine chromatin } \\
\text { and small nucleoli, } \\
\text { limited mitotic } \\
\text { activity, lymphoid } \\
\text { inflammatory } \\
\text { infiltrate }\end{array}$ & Not specified & $\begin{array}{l}\text { NSAIDs, steroids, } \\
\text { vinblastine, } \\
\text { vincristine, } \\
\text { actinomycin-D, } \\
\text { cyclophosphamide), } \\
\text { vinorelbine, } \\
\text { methotrexate; } \\
\text { palliative external } \\
\text { beam radiotherapy }\end{array}$ & Crizotinib & $\begin{array}{l}30 \% \text { volume reduction } \\
\text { within a few weeks } \\
\text { of starting treatment; } \\
\text { intracranial lesions required } \\
\text { radiotherapyy; complete } \\
\text { remission } 3 \text { years after } \\
\text { starting treatment }\end{array}$ \\
\hline $\begin{array}{l}\text { Jacob et al, } \\
2014\end{array}$ & Not described & 45 & $\mathrm{~F}$ & $\begin{array}{l}\text { Multiple liver masses, } \\
\text { lesions in the lumbar } \\
\text { spine }\end{array}$ & $\begin{array}{l}\text { Spindle cell } \\
\text { proliferation, } \\
\text { inflammatory } \\
\text { infiltrate of } \\
\text { lymphocytes, plasma } \\
\text { cells, histiocytes, } \\
\text { and eosinophis; no } \\
\text { necrosis or atypical } \\
\text { mitoses }\end{array}$ & Cytoplasmic & None & Crizotinib & $\begin{array}{l}\text { Complete remission at } \\
\text { 27-month follow-up }\end{array}$ \\
\hline $\begin{array}{l}\text { Kimbara et } \\
\text { al, }{ }^{22} 2014\end{array}$ & RANBP2-ALK & 22 & M & $\begin{array}{l}\text { Pelvic tumor with } \\
\text { invasion of distal } \\
\text { ileum, ascites }\end{array}$ & $\begin{array}{l}\text { Predominately } \\
\text { polygonal tumor cells } \\
\text { with distinct nucleoli } \\
\text { and eosinophilic } \\
\text { cytoplasm; minor } \\
\text { spindle cell } \\
\text { component; nuclear } \\
\text { atypia, mitotic } \\
\text { figures; necrosis; } \\
\text { predominately } \\
\text { neutrophil infiltrate }\end{array}$ & Nuclear membrane & $\begin{array}{l}\text { Two surgical } \\
\text { excisions, doxorubicin }\end{array}$ & Crizotinib & $\begin{array}{l}\text { Tumor shrinkage } 1 \text { month } \\
\text { after starting therapy; } \\
\text { complete remission at } 10 \\
\text { months after starting therapy }\end{array}$ \\
\hline $\begin{array}{l}\text { Kiratli et al. }{ }^{12} \\
2016\end{array}$ & Not described & 7 & $\mathrm{~F}$ & Right eye mass & $\begin{array}{l}\text { Hyalinized connective } \\
\text { tissue with spindle } \\
\text { cells, infilitrate of } \\
\text { lymphocytes, plasma } \\
\text { cells, and histiocytes; } \\
\text { Ki-67 proliferation } \\
\text { index of } 5 \%\end{array}$ & Cytoplasmic & None & Crizotinib & $\begin{array}{l}\text { Complete remission at } 12 \\
\text { months; crizotinib held } \\
\text { but patient with recurrent } \\
\text { disease within } 3 \text { months; } \\
\text { crizotinib restarted; complete } \\
\text { remission } 14 \text { months after } \\
\text { starting second course of } \\
\text { crizotinib therapy }\end{array}$ \\
\hline $\begin{array}{l}\text { Liu et al, } 23 \\
2015\end{array}$ & RANBP2-ALK & 22 & M & $\begin{array}{l}\text { Right abdominal } \\
\text { mass, enlarged lymph } \\
\text { nodes }\end{array}$ & $\begin{array}{l}\text { Many cell types, } \\
\text { varied structure; } \\
\text { rounded, epithelioid } \\
\text { cells with round, } \\
\text { vesicular nuclei, } \\
\text { large nucleoli, } \\
\text { and amphophilic } \\
\text { cytoplasm; spindle } \\
\text { cell component; } \\
\text { mitotic activity } \\
\text { 1-5 per HPF; } \\
\text { inflammatory } \\
\text { infiltrate, } \\
\text { predominantly } \\
\text { neutrophils; focal } \\
\text { necrosis }\end{array}$ & $\begin{array}{l}\text { Cytoplasmic and } \\
\text { perinuclear }\end{array}$ & Surgical excision & Crizotinib & $\begin{array}{l}\text { Complete remission at } 16 \\
\text { months }\end{array}$ \\
\hline
\end{tabular}

(continued on next page)

Abbreviations: ARDS, acute respiratory distress syndrome; BSO, bilateral salpingo-oophorectomy; F, female; HPF, high-power field; IMT, inflammatory myofibroblastic tumor; M, male; NSAID, nonsteroidal anti-inflammatory drug; RUQ, right upper quadrant.

resumed after a 4-week break. However, because of recurrent pneumonitis 3 weeks after resuming crizotinib, a decision was made to transition to alectinib to exclude the possibility that crizotinib was contributing to her pulmonary symptoms. Her pneumonitis and transaminitis resolved with the change to alectinib and with a second course of prednisone. At the time of writing, she continues to do well clinically, with evidence of a near complete response on staging studies at 13 months (Figure 1C).

\section{Discussion}

This study is the first to our knowledge to describe the NUMA1-ALK fusion in IMT and demonstrate the effectiveness of the ALK inhibitors, crizotinib and alectinib, in the management of this IMT variant.

The NUMA1-ALK fusion has not been previously documented in public databases, including The Cancer Genome Atlas (TCGA), the International Cancer Genome Consortium (ICGC), and the Catalogue of Somatic Mutations in Cancer (COSMIC). 
NUMA1-ALK IMT Responds to ALK Inhibition

\begin{tabular}{|c|c|c|c|c|c|c|c|c|c|}
\hline Study & $A L K$-Fusion & Age, & Sex & $\begin{array}{l}\text { Organ } \\
\text { Involvement }\end{array}$ & $\begin{array}{l}\text { Pathology } \\
\text { Features, } \\
\text { General }\end{array}$ & $\begin{array}{l}\text { ALK } \\
\text { Localization }\end{array}$ & $\begin{array}{l}\text { Prior Systemic } \\
\text { Therapies }\end{array}$ & $\begin{array}{l}\text { ALK } \\
\text { Inhibitor }\end{array}$ & $\begin{array}{l}\text { Response/ } \\
\text { Management }\end{array}$ \\
\hline $\begin{array}{l}\text { Lorenzi et al, } \\
2014\end{array}$ & CLTC-ALK & 24 & $\mathrm{M}$ & $\begin{array}{l}\text { Multiple abdominal } \\
\text { masses, including a } \\
\text { liver mass }\end{array}$ & $\begin{array}{l}\text { Spindle cells } \\
\text { with ovoid } \\
\text { nucle containing } \\
\text { prominent nucleoli } \\
\text { and eosinophilic } \\
\text { cytoplasm; } \\
\text { inflammatory } \\
\text { infiltrate with } \\
\text { lymphocytes, } \\
\text { neutrophils, } \\
\text { eosinophils, and } \\
\text { plasma cells; minute } \\
\text { necrotic foci, mitotic } \\
\text { index of } 7 \text { mitoses/10 } \\
\text { HPF; Ki67 index 10\% }\end{array}$ & $\begin{array}{l}\text { Cytoplasmic } \\
\text { (granular) }\end{array}$ & $\begin{array}{l}\text { Surgery, without } \\
\text { resection of hepatic } \\
\text { mass }\end{array}$ & Crizotinib & $\begin{array}{l}\text { Stable disease } 4 \text { months after } \\
\text { starting treatment }\end{array}$ \\
\hline $\begin{array}{l}\text { Mansfield et } \\
\mathrm{al}^{26} 2016\end{array}$ & TPM3-ALK & 32 & M & $\begin{array}{l}\text { Tumor involving left } \\
\text { lung and chest wall, } \\
\text { medial right thigh, } \\
\text { right gluteal muscle } \\
\text { and omentum }\end{array}$ & $\begin{array}{l}\text { Myofibroproliferation } \\
\text { with inflammatory } \\
\text { infiltrate of plasma } \\
\text { cells and eosinophils }\end{array}$ & Not described & Prednisone & Crizotinib & $\begin{array}{l}\text { Partial response, but } \\
\text { subsequent disease } \\
\text { progression after } 8 \text { months; } \\
\text { treated with celecoxib - } \\
\text { further progression; then } \\
\text { started on ceritinib } 750 \mathrm{~g} \\
\text { daily, reduced to } 600 \mathrm{mg} \\
\text { daily after developing } \\
\text { nausea; partial response to } \\
\text { ceritinib after } 8 \text { weeks of } \\
\text { treatment; recurrence noted } \\
\text { at } 18 \text { months }\end{array}$ \\
\hline $\begin{array}{l}\text { Ono et al, } 27 \\
2016\end{array}$ & RANBP2-ALK & 57 & M & $\begin{array}{l}\text { Right intrapleural } \\
\text { lesion, chest wall } \\
\text { invasion, mediastinal } \\
\text { lymph node } \\
\text { metastasis, pleural } \\
\text { dissemination }\end{array}$ & Not described & Not described & $\begin{array}{l}\text { ASP3026, } 125 \mathrm{mg} \\
\text { once daily }\end{array}$ & Ceritinib & $\begin{array}{l}\text { Partial response at } 6 \text { months } \\
\text { after starting ceritinib; } \\
\text { disease progression at } \\
11 \text { months after starting } \\
\text { ceritinib; crizotinib, cisplatin, } \\
\text { pemetrexed given - no tumor } \\
\text { response; received palliative } \\
\text { radiation, whole-brain } \\
\text { radiation; patient died }\end{array}$ \\
\hline $\begin{array}{l}\text { Shash et } \mathrm{al}_{,}^{28} \\
2016\end{array}$ & TPM3-ALK & 8 & $\mathrm{~F}$ & $\begin{array}{l}\text { Left lower lobe lung } \\
\text { mass }\end{array}$ & $\begin{array}{l}\text { Heterogenous with } \\
\text { myofibroblastic } \\
\text { spindle cells, and } \\
\text { polygonal cells with } \\
\text { prominent nucleoli } \\
\text { and atypical mitotic } \\
\text { figures; inflammatory } \\
\text { infiltrate of } \\
\text { lymphocytes, } \\
\text { neutrophils, and } \\
\text { plasma cells; } \\
\text { extensive necrosis, } \\
\text { lymphovascular } \\
\text { invasion }\end{array}$ & Cytoplasmic & Surgical resection & Crizotinib & $\begin{array}{l}\text { Minimal FDG uptake after } 3 \\
\text { months of therapy; patient } \\
\text { died of ARDS } 4 \text { months after } \\
\text { starting crizotinib therapy, } \\
\text { but no evidence of IMT } \\
\text { tumor at time of death }\end{array}$ \\
\hline $\begin{array}{l}\text { Subbiah et } \\
a^{1},{ }^{13} 2015\end{array}$ & DCTN1-ALK & $\approx 50$ & $\mathrm{~F}$ & Uterine mass & Not described & Not described & $\begin{array}{l}\text { Surgical resection } \\
\text { (BSO, pelvic } \\
\text { lymphadenectomy, } \\
\text { omentectomy) }\end{array}$ & $\begin{array}{l}\text { Crizotinib and } \\
\text { pazopanib }\end{array}$ & $\begin{array}{l}\text { Partial response after two } 21-\text { - } \\
\text { day cycles of therapy; partial } \\
\text { remission } 6 \text { months after } \\
\text { starting therapy }\end{array}$ \\
\hline Present study & NUMA1-ALK & 21 & $\mathrm{~F}$ & $\begin{array}{l}\text { Tumor involving the } \\
\text { mediastinum and left } \\
\text { hemithorax, bilateral } \\
\text { lungs, pleura, liver, } \\
\text { spleen, peritoneum, } \\
\text { left kidney, axial } \\
\text { skeleton, and iliacus } \\
\text { muscle }\end{array}$ & $\begin{array}{l}\text { Spindle cell } \\
\text { proliferation with } \\
\text { broad areas of } \\
\text { fibrosis and obscuring } \\
\text { lymphoplasmacytic } \\
\text { infiltrates, without } \\
\text { evidence of high- } \\
\text { grade anaplastic } \\
\text { features, coagulation } \\
\text { tumor necrosis, or } \\
\text { atypical mitotic } \\
\text { figures }\end{array}$ & $\begin{array}{l}\text { Cytoplasmic and } \\
\text { perinuclear }\end{array}$ & None & $\begin{array}{l}\text { Crizotinib and } \\
\text { alectinib }\end{array}$ & $\begin{array}{l}\text { Near complete response on } \\
\text { staging studies at } 7 \text { months }\end{array}$ \\
\hline
\end{tabular}

Abbreviations: ARDS, acute respiratory distress syndrome; BSO, bilateral salpingo-oophorectomy; F, female; HPF, high-power field; IMT, inflammatory myofibroblastic tumor; M, male; NSAID, nonsteroidal anti-inflammatory drug; RUQ, right upper quadrant.

However, numerous other ALK fusions have been recorded in the context of $\mathrm{IMTs}^{5}$ and are thought to drive tumor formation by activating the ALK tyrosine kinase, a member of the insulin receptor family. ${ }^{15}$ ALK-positive IMTs have previously demonstrated an excellent response to ALK inhibitors such as crizotinib ${ }^{8-13}$ and ceretinib. ${ }^{14}$ In the present case, an IMT with a novel NUMA1-ALK fusion also demonstrated a marked initial response to crizotinib, and ongoing response to the second-generation ALK inhibitor alectinib.
The fact that our patient had metastatic disease despite the absence of high-grade anaplastic features and necrosis on histology was not unprecedented; favorable histologic characteristics do not necessarily predict a favorable clinical course in IMT. ${ }^{16}$ However, ALK positivity usually predicts localized disease $^{16-18}$ with the exception of the epithelioid variant of IMT, driven by the RANBP2-ALK or RRBP1-ALK fusions. ${ }^{19,20}$ Epithelioid inflammatory myofibroblastic sarcoma, in contrast to most IMTs that demonstrate ALK staining in a cytoplasmic pattern, ${ }^{1}$ demon- 
strates ALK staining in a nuclear membrane or perinuclear pattern. ${ }^{19}$ Interestingly, our patient's tumor also showed ALK reactivity in a perinuclear pattern, likely reflecting the nuclear localization of the nuclear mitotic apparatus (NUMA) protein, which contributes to chromosome separation and nuclear rebuilding during cell division. ${ }^{21}$

In cases of ALK-driven IMT treated with ALK inhibitors, our review of the literature demonstrated no obvious association between histologic features and response to ALK inhibitor therapy (Table 1). Abdominal organ involvement rather than lung involvement at presentation may also be associated with a more favorable response to ALK inhibitor therapy. All cases initially involving abdominal organs showed either complete remission 10 to 30 months after starting therapy (4/5 patients) $)^{10,11,22,23}$ or stable disease 4 months after starting therapy $(1 / 5$ patients). ${ }^{8}$ In contrast, 3 of 4 cases with initial lung involvement demonstrated poor outcomes with ALK inhibitor therapy: 2 were characterized by disease progression at 8 and 11 months, ${ }^{24,25}$ and 1 patient with pulmonary involvement died of acute respiratory distress syndrome 4 months into treatment despite marked radiographic response to crizotinib. ${ }^{26}$ More data are needed to definitively compare abdominal and pulmonary IMT and the potential role of tumor microenvironment on ALK inhibitor response. We note that disease progression on prior ALK inhibitor therapy is, not surprisingly, associated with poor response to subsequent ALK inhibition: both cases in our literature review showed rapid disease progression (Table 1). ${ }^{24,25}$

The present study highlights the strengths and limitations of IHC, FISH, and NGS in the diagnosis and management of IMTs. Our false-negative FISH results may have arisen from a conservative threshold for positivity, incorrect probe hybridization, DNA folding, nuclear sectioning, or tumor heterogeneity. ${ }^{27,28}$ Ambiguity regarding ALK reactivity can prevent the timely use of ALK inhibitors effective against ALK-positive IMT; IHC showing ALK reactivity may be sufficient grounds to initiate treatment with ALK inhibitors. ${ }^{9}$ However, NGS may help resolve discrepancies between IHC and FISH in the process of diagnosing IMT.

\section{Conclusions}

This report presents a 21-year-old woman with widely metastatic IMT driven by a novel NUMA1-ALK fusion. Although the ultimate durability of her response is unknown and the emergence of resistance to ALK inhibitors is well described in other ALKrelated malignancies, ${ }^{29}$ treatment with the ALK inhibitors crizotinib and alectinib has thus far led to a deep and sustained response of $\geq 13$ months. Notably, this therapy was initiated at a comprehensive cancer center with experience managing IMTs; we strongly recommend multidisciplinary evaluation at an experienced center for all patients with newly diagnosed IMTs, and encourage all centers that engage in the treatment of IMTs to pursue prospective collection of clinical disease features, coupled with comprehensive molecular characterization of tumors, ${ }^{30}$ with the goal of characterizing the full spectrum of oncogene fusions in IMT, determining the prognosis associated with each variant, and predicting the response of each variant to kinase inhibitor therapy. Sharing these data through existing cancer databases (ClinicalTrials.gov identifier: NCT02677961) will be essential for progress in managing this disease. .11,32 $^{2}$

\section{References}

1. Gleason BC, Hornick JL. Inflammatory myofibroblastic tumours: where are we now? J Clin Pathol 2008;61:428-437.

2. Fletcher CD, Unni KK, Mertens F, eds. World Health Organization Classification of Tumours. Pathology and Genetics of Tumours of Soft Tissue and Bone. Lyon, France: IARC Press; 2002.

3. Coffin CM, Watterson J, Priest JR, Dehner LP. Extrapulmonary inflammatory myofibroblastic tumor (inflammatory pseudotumor). A clinicopathologic and immunohistochemical study of 84 cases. Am J Surg Pathol 1995;19:859-872.

4. Pulford K, Lamant L, Morris SW, et al. Detection of anaplastic lymphoma kinase (ALK) and nucleolar protein nucleophosmin (NPM)-ALK proteins in normal and neoplastic cells with the monoclonal antibody ALK1. Blood 1997;89:1394-1404.

5. Minoo P, Wang HY. ALK-immunoreactive neoplasms. Int J Clin Exp Pathol 2012;5:397-410.

6. Coffin CM, Patel A, Perkins S, et al. ALK1 and p80 expression and chromosomal rearrangements involving $2 \mathrm{p} 23$ in inflammatory myofibroblastic tumor. Mod Pathol 2001;14:569-576.

7. Sokai A, Enaka M, Sokai R, et al. Pulmonary inflammatory myofibroblastic tumor harboring EML4-ALK fusion gene. Jpn J Clin Oncol 2014;44:93-96.

8. Lorenzi L, Cigognetti M, Medicina D, et al. ALK-positive inflammatory myofibroblastic tumor of the abdomen with widespread microscopic multifocality. Int J Surg Pathol 2014;22:640-644.

9. Gaudichon J, Jeanne-Pasquier C, Deparis M, et al. Complete and repeated response of a metastatic ALK-rearranged inflammatory myofibroblastic tumor to crizotinib in a teenage girl. J Pediatr Hematol Oncol 2016;38:308311.

10. Jacob SV, Reith JD, Kojima AY, et al. An unusual case of systemic inflammatory myofibroblastic tumor with successful treatment with ALKinhibitor. Case Rep Pathol 2014;2014:470340. 
NUMA1-ALK IMT Responds to ALK Inhibition

11. Butrynski JE, D'Adamo DR, Hornick JL, et al. Crizotinib in ALK-rearranged inflammatory myofibroblastic tumor. N Engl J Med 2010;363:1727-1733.

12. Kiratli H, Uzun S, Varan A, et al. Management of anaplastic lymphoma kinase positive orbito-conjunctival inflammatory myofibroblastic tumor with crizotinib. J AAPOS 2016;20:260-263.

13. Subbiah V, McMahon C, Patel S, et al. STUMP un"stumped": anti-tumor response to anaplastic lymphoma kinase (ALK) inhibitor based targeted therapy in uterine inflammatory myofibroblastic tumor with myxoid features harboring DCTN1-ALK fusion. J Hematol Oncol 2015;8:66.

14. Nishio M, Murakami $H$, Horiike A, et al. Phase I study of ceritinib (LDK378) in Japanese patients with advanced, anaplastic lymphoma kinase-rearranged non-small-cell lung cancer or other tumors. J Thorac Oncol 2015;10:1058-1066.

15. Morris SW, Kirstein MN, Valentine MB, et al. Fusion of a kinase gene, ALK, to a nucleolar protein gene, NPM, in non-Hodgkin's lymphoma. Science 1994;263:1281-1284.

16. Coffin CM, Hornick JL, Fletcher CD. Inflammatory myofibroblastic tumor: comparison of clinicopathologic, histologic, and immunohistochemical features including ALK expression in atypical and aggressive cases. Am J Surg Pathol 2007;31:509-520.

17. Debelenko LV, Arthur DC, Pack SD, et al. Identification of CARS-ALK fusion in primary and metastatic lesions of an inflammatory myofibroblastic tumor. Lab Invest 2003;83:1255-1265.

18. Sethi B, Pai T, Allam A, Epari S. Anaplastic lymphoma kinase-positive pulmonary inflammatory myofibroblastic tumor with sarcomatous morphology and distant metastases: an unusual histomorphology and behavior. Indian J Pathol Microbiol 2015;58:509-512.

19. Marino-Enriquez A, Wang WL, Roy A, et al. Epithelioid inflammatory myofibroblastic sarcoma: An aggressive intra-abdominal variant of inflammatory myofibroblastic tumor with nuclear membrane or perinuclear ALK. Am J Surg Pathol 2011;35:135-144.

20. Lee JC, Li CF, Huang HY, et al. ALK oncoproteins in atypical inflammatory myofibroblastic tumours: novel RRBP1-ALK fusions in epithelioid inflammatory myofibroblastic sarcoma. J Pathol 2017;241:316-323.

21. Compton DA, Cleveland DW. NuMA is required for the proper completion of mitosis. J Cell Biol 1993;120:947-957.
22. Kimbara S, Takeda K, Fukushima H, et al. A case report of epithelioid inflammatory myofibroblastic sarcoma with RANBP2-ALK fusion gene treated with the ALK inhibitor, crizotinib. Jpn J Clin Oncol 2014;44:868871.

23. Liu Q, Kan Y, Zhao Y, et al. Epithelioid inflammatory myofibroblastic sarcoma treated with ALK inhibitor: a case report and review of literature. Int J Clin Exp Pathol 2015;8:15328-15332.

24. Mansfield AS, Murphy SJ, Harris FR, et al. Chromoplectic TPM3-ALK rearrangement in a patient with inflammatory myofibroblastic tumor who responded to ceritinib after progression on crizotinib. Ann Oncol 2016;27:2111-2117.

25. Ono A, Murakami H, Serizawa $M$, et al. Drastic initial response and subsequent response to two ALK inhibitors in a patient with a highly aggressive ALK-rearranged inflammatory myofibroblastic tumor arising in the pleural cavity. Lung Cancer 2016;99:151-154.

26. Shash H, Stefanovici C, Phillips S, Cuvelier GD. Aggressive metastatic inflammatory myofibroblastic tumor after allogeneic stem cell transplant with fatal pulmonary toxicity from crizotinib. J Pediatr Hematol Oncol 2016;38;642-645.

27. Tan LH, Do E, Tan SY, et al. Multi-lineage interrogation of the performance characteristics of a split-signal fluorescence in situ hybridization probe for anaplastic lymphoma kinase gene rearrangements: a study of 101 cases characterized by immunohistomorphology on fixed archival tissue. Mol Diagn 2004;8:213-229.

28. Katzman PJ. Variable ALK protein and ALK gene staining in inflammatory myofibroblastic tumors. Pediatr Dev Pathol 2013;16:232-233.

29. Mologni L. Current and future treatment of anaplastic lymphoma kinaserearranged cancer. World J Clin Oncol 2015;6:104-108.

30. Lovly CM, Gupta A, Lipson D, et al. Inflammatory myofibroblastic tumors harbor multiple potentially actionable kinase fusions. Cancer Discov 2014;4:889-895.

31. Oncology Research Information Exchange Network. Available at: http:// oriencancer.org/\#about. Accessed March, 7, 2017.

32. ASCO CancerLinQ. Available at: https://cancerlinq.org/. Accessed March, 7, 2017. 